\title{
Antecedents of Consumer Intentions for Halal Tourism: Comparing between Perceptions of Generation $Y$ and $Z$
}

\author{
$1^{\text {st }}$ Julina Julina ${ }^{1}, 2^{\text {nd }}$ Bambang Kariyawan ${ }^{2}$ \\ \{julina@uin-suska.ac.id ${ }^{1}$, bkariyawan090571@gmail.com² ${ }^{2}$, \\ UIN Syarif Kasim Riau, Pekanbaru, Indonesia ${ }^{1}$, SMA Cendana Pekanbaru, Komplek CPI, \\ Pekanbaru, Indonesia ${ }^{2}$
}

\begin{abstract}
Abtract. This study aims to compare the antecedents of Halal tourism between generations $\mathrm{Y}$ and Z. Data were collected using a questionnaire distributed online with accidental techniques and snowball sampling. After testing the validity and reliability of the data were analyzed using multiple linear regression. The results of the study prove that there are differences in factors affecting the intention of Halal tourism between the two groups studied. Subjective norm is the only variable that affects Generation Y for Halal tourism intentions, while in the Generation $\mathrm{Z}$ sample only attitudes and religiosity affect Halal tourism intentions.
\end{abstract}

Keywords: Intention, Halal Tourism, Y and Z Generation

\section{Introduction}

Today there are many Muslims who like to travel. In fact, it is not uncommon for Muslims to make traveling as a hobby. However, many consider that traveling is a waste of money. In fact, traveling is not just a waste of money but can be used as a medium of learning and life experience. In traveling, we will get experience from positive or negative aspects. It all depends on how perception, perspective, and return to the intention of the traveler. If the aim is to connect with others, to seek knowledge, which is part of worship, it is highly recommended.

One of the verses in the Koran that describe traveling is Surah Al Mulk Verse 18 which means "He is the one who makes the earth easy for you, so walk in all directions and eat some of his sustenance. And only to Him are you (returned after) resurrected." In addition, Surah Luqman Verse 31 also encourages us to understand the greatness of God when we travel. The verse said "Did you not notice that the ship actually sailed in the sea with the pleasure of Allah, so that He showed you some of His signs (power). Indeed, in that case, there were really signs for everyone who is very patient and much grateful." Then, in a hadith, Rasulullah SAW once said related to positive things that can be done when traveling, namely: "Looking for knowledge is mandatory for every male and female Muslim". (Narrated by Ibnu Abdil Barr).

Indonesia with a majority Muslim population has the potential to become a major tourist destination, especially Halal tourism. However, according to research from Vargas-sanchéz \& Perano (2018), scientific research on Halal tourism in Indonesia is still very few [1]. In 
addition, there are not many of their research samples that claim to be familiar with the concept of Halal tourism. Therefore, this study wants to examine more deeply about Halal tourism and what are the factors that influence it.

The target population in this study is the Millennial (Y) and Post Millennial ( $\mathrm{Z}$ ) generation. Generation $\mathrm{Y}$ is the generation born between 1982-1994. Work-life balance, that is the motto of most millennials. It is not only the pursuit of wealth, but the millennial is more about the pursuit of solidarity, shared happiness, and self-existence to be socially valued. In addition to experiencing the transition from everything that is analogous to digital, millennial or generation $\mathrm{Y}$ also grows along with the maturity of equality and human rights values, thus influencing their nature that can be judged more democratic. Even though their lives seem to be always having fun, this generation is predicted to have a lot of good influence on the nation's future.

Generation $\mathrm{Z}$ is the generation born between 1995-2010. With the rapid development of technology in the $\mathrm{Z}$ generation, they seem unable to escape from gadgets and social media activities. 44 percent of Gen $Z$ check social media at least every hour. As a result, they are faster in obtaining information than in previous generations. Although they like things that are instant, this generation still has advantages not much different from almost like the 'older siblings'. Technology for them can do anything including studying and working, not just having fun. So not a few of Gen $Z$ who now use social media as their land to make a living. Like opening an online shop or becoming a young influencer. The comparison between the two generations will determine whether marketers need to present different marketing communications for the two segments.

\section{Literature Review}

To build a research model, it will first be discussed about Halal tourism and subsequently will be discussed several variables that become antecedents for consumer intentions to visit Halal tourism destinations.

\subsection{Halal Tourism}

The few papers that discuss Halal tourism are found in detail in articles written by Vargas-Sanchez and Perano (2018). Citing data from the Web of Science, they found only 13 publications on Halal tourism during 2014-2016 [1]. Another article written by Bogan and Sariisik (2018) found that in the existing literature, the term Halal tourism is often substituted with other terms, for example, Islamic tourism, Muslim-friendly tourism, Shari'ah tourism, and Islamic travel [2]. Therefore, perhaps in fact many papers have discussed this topic but use different terms so that when only referring to one term only a few research is detected. Khan and Callanan found that the term Islamic tourism is more often used in the academic world than Halal tourism. Battour and Ismail as cited in Bogan and Sariisik (2018) define the term halal as "the practices or activities allowed by the Islamic teachings" $(2015$, p. 2$)$. The halal tourism is defined by World Travel Market (2007) as "a type of religious tourism that represents allowable activities under the Islamic teachings in terms of behavior, dress, conduct, and diet". Besides the different terms, there are those who assume that each term does have a different meaning. Bogan and Sariisik (2018) conducted a literature study and summarized the different definitions of Islamic tourism and Halal tourism. 
According to the CEO of CrescentRating and HalalTrip, Bahardeen "People started to get to know the halal tourism market in 2008. Since then people have become interested and are aware of the potential of Muslim tourists." Halal tourism is no longer just a halal certification restaurant or a place of worship for Muslims. More than that, halal tourism is now growing with technology that makes it easier for tourists. He further explained in 2014-2018 the tourism industry began to organize halal travel tours, which are also called Halal Travel 1.0. Whereas this year, halal tourism developed into Halal Travel 2.0. here are three keys in Halal Travel 2.0 namely technology, social activities, and demographics. All three will affect halal tourists and bring change. Halal tourism is a complete tourism destination with halal facilities and Moslem friendly tourism. Examples of criteria that must be in halal destinations are easy to find mosques, places of ablution, hotels have qibla direction, prayer times, holy books, and so on. Indonesia is a country with the largest Muslim population in the world, by default it can be said that our tourism is halal tourism [3].

The definition of halal tourism according to academics M. Battor and N. Nazari Ismail are all objects or actions that are allowed according to Islamic teachings to be used or engaged by Muslims in the tourism industry. This definition views Islamic law (sharia) as the basis for providing tourism products and services for consumers (in this case Muslim), such as halal hotels, halal resorts, halal restaurants, and halal travel. This definition is not limited to Muslim countries. All halal tourism indicators can also be applied to non-Muslim countries. In addition, halal tourism is not limited to religious trips, such as the Wali Songo, pilgrimage, but also trips that are general in nature and can be enjoyed by all walks of life.

Joining and winning the international halal tourism competition is an effective way to promote halal tourism in particular and Indonesian tourism in general. Indonesian tourism will be increasingly known and its value in the eyes of the world will be even higher. In this way, it is hoped that the tourism sector can increase gross domestic product (GDP) income, foreign exchange, and the number of jobs.

Indonesian halal tourism tends to increase. Indonesia is the best in the 2019 Global Muslim Travel Index (GMTI). Indonesia is number 1 in 130 countries in the world. Because, after years of increasing steadily from ranking 6 in 2015, ranking 4 in 2016, ranking 3 in 2017, ranking 2 in 2018, finally Indonesia ranked 1 GMTI in 2019. To develop Halal tourism in the country, the Indonesian government established 10 main halal tourism destinations consisting of Aceh, West Sumatra, Riau, DKI Jakarta, West Java, Central Java, DI Yogyakarta, East Java, Lombok/NTB, and South Sulawesi. However, for now, the government is still focusing on five destinations, namely Aceh, West Sumatra, Lombok, DKI Jakarta and West Java.

Indonesia's ranking is not separated from a variety of improvements made. The improvements include the accessibility, communication, control of environmental factors, to services. For accessibility, significant improvements were made in 5 regions. There are Aceh, West Sumatra, Riau Islands \& Riau Islands, Jakarta, and Lombok. The focus starts from the airport, harbor, road, to the railroad tracks. Communication development is also intensively carried out in the 5 regions. The focus is on developing Muslim Visitor Guides, Education Stakeholders, Market Outreach, Tour Guides, and Digital Marketing. Tourists are also spoiled with a variety of halal tourism support facilities. In the 5 regions, tourist destinations are always supported by certified halal restaurants. The number of places of worship is large and spread evenly. Even similar to the airport that is equipped with prayer rooms. For hotels, the kitchen is halal-certified and the attractions are strong with an Islamic feel.

According to Qaddhat, Attaalla, and Hussein (2016) halal tourism has several supporting components, namely hotels, food, tour packages, transportation, finance, certificates, and logos [4]. Halal compliance hotels have several characteristics such as not providing alcohol 
and only providing halal food; the availability of prayer rooms; the majority are Muslim employees and dress according to Islamic rules; supporting facilities such as salon, spa, swimming pool, gym, etc. which are separate for men and women; available Alquran, prayer mat, and Qibla direction in the room; etc. The next component of Halal tourism is food. Islam is very detailed in regulating what foods and drinks are allowed to be eaten and drunk. Bogan and Sariisik (2019) assume that although they are both Muslim, they implement it differently. This shows that they are a heterogeneous market so that the criteria for determining halal hotels must have different qualifications [2].

\subsection{Consumer Intention}

Since 2015, Shakona, et al have emphasized marketers to pay attention to the influence of Islam on traveler behaviour [5]. This is because the estimated growth of the Muslim market will reach the US \$ 2.6 trillion by 2020 , or an average growth of $6.3 \%$ per year, while Muslim tourism growth is predicted to be even higher, which is $9.1 \%$ per year. According to Rashid (2018), not all people visiting religious attractions have the religious motivation and may have heritage/secular motivation. He distinguishes between Islamic tourism and Islamic religious tourism. Islamic tourism visiting various tourist objects is not for religious purposes but still maintaining the rules of religion, for example in choosing food that has a Halal label. So, if the tourists who are traveling are not for worship purposes only, they must be very careful in maintaining the rules of their religion, especially tourists who travel for the purpose of worship according to their religion. Unlike conventional products which may contain content that is prohibited in Islam, halal products can generally be consumed by anyone, including non-Muslims [6].

There abundant research has been done relating to purchase intention. Some of them, especially that including Islamic values, will be elaborate in this paper. Suki and Salleh (2018) modified Theory of Planned Behaviour (TPB) by adding one variable that relating to Islamic value, namely halal image as a moderating variable [7]. According to Elias, Othman, and Saifudin (2016) intention is one of the factors that induce people's behavior and how they put some effort to try something different. In their research, the intention and behavior of producing halal products are influenced by halal awareness, knowledge, and economy [8]. Azis and Chok's (2012) research found that Halal awareness and certification had a positive effect on purchase intentions among non-Muslims in Malaysia [9]. This research use TPB as well as independent variable and put one variable religiosity to be measured simultaneously with the TPB.

\subsection{Subjective Norm}

Subjective norm is defined as "the perceived social pressure to perform or not to perform the behavior" (Ajzen, 1991) [10]. According to Vallerand et al (1992), subjective norms are formed by normative beliefs and motivation to comply. In this study, subjective norms are considered to affect consumers' intention to visit cities with the concept of Halal tourism [11]. Socially, consumers will not be pressured when visiting the city, where in addition to benefiting from traveling there is also no concern in carrying out daily activities as a Muslim. In their paper, Syahirah and Mohamed (2016) propose a positive relationship between norms and purchase intention of halal hotel services [12]. Even farther, Nursalwani and Zulariff (2017) have found that subjective norms have positive effect on intention to buy chocolate bar 
that has halal label. This argument forms the basis of the formation of the following hypothesis:

H1: Subjective norm is positively influence intention for Halal tourism.

\subsection{Attitude}

Attitude toward the behavior is referred to as "the degree to which a person has a favorable

or unfavorable evaluation of the behavior in question" (Ajzen, 1991) [10]. According to Vallerand et al (1992) attitude is formed by behavioral beliefs and outcome evaluation. As the most relevant component of TPB, attitude toward behavior, which is originated from a collective behavioral belief such as the belief that the visiting city with the concept of Halal tourism will encourage the intention to visit the city [11]. The results of these studies form the basis of the formation of the following hypothesis:

H2: Attitude is positively influence intention for Halal tourism.

\subsection{Perceived Behavioural Control}

Perceived behavioral control is related to "the perceived ease or difficulty of performing the behavior of interest" (Ajzen, 1991) [10]. According to Aziz and Chok (2012) research on halal is still in the initial stages. Many studies have tested the intention to purchase halal products using TPB and TRA as a basis for understanding consumer behaviour towards halal perceptions [9]. Research by Suki and Salleh (2016) found that perceived behavioural control significantly influence intention to patronize halal store [13]. In 2018, using halal image as the mediating variable, they still found the important role of perceived behavioural control on intention. Nursalwani and Zulariff (2017) even farther put in the evidence of the strong relationship between perceived behavioural control and intention. In their research, the intention to consume halal labelled chocolate bar is influenced by perceived behavioural control as one of variable in TPB. The results of these studies form the basis of the formation of the following hypothesis:

H3: Perceived Behavioral Control is positively influence intention for Halal tourism

\subsection{Religiosity}

McDaniel and Burnett, (1990) define religiosity as "A belief in God accompanied by a commitment to follow principles believed to be set forth by God" [14]. The impact of religion on consumer behaviour have been well documented. Awan et al (2015) stated that its impact will depend on consumer's religiosity, so that in choosing a place to visit. Restriction of halal food only to be consume will determine consumer's preference on travelling [15]. Haq and Wong's (2010) study from previous research concludes that there are three types of journey in Islam, namely hajj/umrah, rihla, or ziyara. Hajj and umrah are very special for Muslims only. Umrah does not require a specific time while the Hajj has been determined based on the Islamic calendar. In addition to travel for the main purpose of carrying out worship to God, in Islam, there are also known trips that aim to seek knowledge, trade, seek treatment, and conduct research commonly called Rihla. The third form of travel that is usually done by 
Muslims is ziyara, that is visits to shrines, mosques, or monasteries for spiritual growth and devotion towards the famous spiritual people [16]. Suggestions in Islam for adherents to make a useful journey become the basis of the formation of the following hypothesis:

H4: Religiosity is positively influence intention for Halal tourism

Based on the previous discussion, this research proposes a research model as shown in Figure 1.

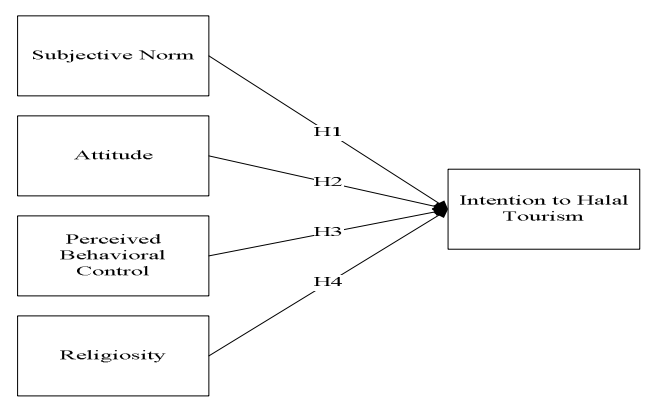

Fig. 1. Proposed Model

\section{Method}

Respondents in this study were generation $\mathrm{Y}$ and $\mathrm{Z}$ obtained using accidental and snowball sampling. Researchers gave questionnaires to several people they met and were then asked to pass on the questionnaire to their colleagues. The questionnaire sent was arranged into three parts. The first part asks the respondent's identity, the second part contains the variables that are the focus of research and the third part is open questions about various matters related to Halal tourism. The variables examined in this study are the subjective norm, attitude, perceived behavioral control, religiosity, and intention to Halal tourism. The data collected was analyzed for validity and reliability. After passing through the two tests, the data were analyzed using multiple linear regression.

\section{Result and Discussion}

\subsection{Descriptive Analytics}

Table 1 illustrates the respondents' descriptive data. the majority of respondents have never heard of halal tourism. Most respondents have often traveled between 5 and 10 times. Due to the lack of literature on Halal tourism as stated by Vargas-Sanchez and Perano (2018) [1], it is not surprising that the term Halal tourism is not yet familiar among the people. Their results found that only $38 \%$ of respondents were familiar with the term. Another study by Krishnan et al. (2017) in Malaysia also found a broad lack of awareness among members of Generation $\mathrm{Z}$ towards Halal food, and in general the Halal concept [17]. However, the results of this study found little difference between respondents who had heard of Halal tourism and 
those who had not. As many as $48 \%$ of respondents claimed to have heard and the remaining $52 \%$ of respondents said they had never heard of Halal tourism.

The Indonesian government has established three main strategies to accelerate the development of halal tourism. First, Global Leadership. Supposedly for halal tourism, Indonesia is the leader. For this reason, in every meeting or competition, Indonesia must become a champion. Indonesia has won 12 of the 16 award categories at the 2016 World Halal Tourism Award and the 2016 International Travel Week in Abu Dhabi. Last year Indonesia also held a halal tourism competition with 14 categories that were contested and intended not only for destinations but also including hotels, airports, and travel agents. The government must also continue to improve our ranking in GMTI as a global standard in assessing the competitiveness of halal tourism. Second, marketing strategies using the formulated Destination, Origination, and Time (DOT) models. Which destinations will be offered, which originations/markets will be targeted, and when they will do what must be formulated in detail. For the promotion strategy, the Branding, Advertising, and Selling (BAS) models are used. While for the media strategy the Paid, Owned, Social Media and Endorser (POSE) models are used. Third, Development of Destinations and Institutions. The government develops and strengthens the competitiveness of attractions and products to further embed the Indonesian state as the main destination for halal tourism in the world. The programs carried out include the development of halal tourism destinations and industries and increasing the capacity of industry players. Furthermore, the government strengthens the halal tourism ecosystem by providing input for improvement and development to all tourism stakeholders, preparing training curriculum for halal tourism human resources, and of course, educating the public to be increasingly concerned with halal tourism.

Table 1. Respondents Demographic Profile

\begin{tabular}{lcc}
\hline \multicolumn{1}{c}{ Variable } & Frequency & $(\%)$ \\
\hline Age (Years) & & \\
Generation $Z$ & & 1 \\
$\leq 13$ & 1 & 16 \\
$14-18$ & 11 & 83 \\
$19-24$ & 58 & \\
Generation $Y$ & & 63 \\
$25-29$ & 25 & 23 \\
$30-33$ & 9 & 15 \\
$34-38$ & 6 & \\
& & \\
Hear about Halal tourism & & 48 \\
Yes & 55 & 52 \\
No & 59 & \\
& & \\
Take a tour (times) & & 30 \\
$<5$ & 35 & 38 \\
$5-10$ & 44 & 8 \\
$11-15$ & 9 & 24 \\
$>15$ & 27 & \\
\hline
\end{tabular}

As a country with a majority Muslim population, several characteristics of Halal tourism are easily found in Indonesia. However, only a few cities are considered suitable for bearing the title as Halal tourism. The results of respondents' answers in this study $63 \%$ answered 
Aceh, 24\% West Sumatra, 10\% Riau and the rest are divided into several other provinces. Two of these provinces, Aceh and West Sumatra have indeed been targeted by the government to be developed as a Halal tourism market, while Riau is included in the next priority of the 10 cities declared as Halal tourism cities. Research from Anismar, Satria, and Ali (2018) found that Halal tourism is very suitable to be applied there because Halal tourism is a reflection of the people of Aceh, especially Aceh Singkil as their research location. According to them, the concept of Halal Tourism in Aceh has seriously been discussed and campaigned, but until now it is just a discourse and has not seen any improvement [18].

\subsection{Validity and Reliability Testing}

The internal reliability of the questionnaire is measured using Cronbach's Alpha value. The results of reliability testing showed that all variables had passed the reliability test. The Cronbach's Alpha coefficient that is more than 0.7 is considered acceptable. The lowest reliability in this study is 0.707 for perceived behavioural control of Y generation. The highest reliability for the $\mathrm{Y}$ generation sample is on the religiosity variable, while the $\mathrm{Z}$ generation is on the attitude variable. Pearson Correlation is used to measure the validity of the questionnaire. All Pearson Correlation is more than 0.3 that mean has passed the lowest value for validity. More details can be seen in Table 2

Table 2. Validity and Reliability Testing

\begin{tabular}{cccccc}
\hline \multirow{2}{*}{ Variable } & \multirow{2}{*}{ Indicator } & \multicolumn{2}{c}{ Pearson Correlation } & \multicolumn{2}{c}{ Cronbach's Alpha } \\
& & Gen Y & Gen Z & Gen Y & Gen Z \\
\hline Intention & Y11 & .865 & .853 & & \\
& Y12 & .845 & .861 & .834 & .784 \\
& Y13 & .890 & .803 & & \\
Subjective Norm & X11 & .732 & .860 & & .843 \\
& X12 & .846 & .842 & .793 & \\
& X13 & .848 & .779 & & To \\
& X14 & .727 & .822 & & \\
\end{tabular}

continued

\begin{tabular}{cccccc}
\multicolumn{2}{c}{ Continued } & \multicolumn{2}{c}{ Pearson Correlation } & \multicolumn{2}{c}{ Cronbach's Alpha } \\
\hline \multirow{2}{*}{ Variable } & Indicator & Gen Y & Gen Z & Gen Y & Gen Z \\
\hline Attitude & X21 & .862 & .890 & & \\
& X22 & .902 & .937 & .873 & .912 \\
Perceived & X23 & .916 & .946 & & \\
Behavioral & X31 & .796 & .814 & & \\
Control & X32 & .905 & .905 & .707 & .845 \\
& X33 & .697 & .901 & & \\
Religiosity & X41 & .936 & .918 & & .897 \\
& X42 & .899 & .920 & .904 & \\
\hline & X43 & .925 & .930 & & \\
& X44 & .821 & .742 & & \\
\end{tabular}




\subsection{Multiple Regression Analysis}

The next analysis is multiple linear regression. The results of the analysis can be seen in Tables 3 and 4 . The results of data processing found that the subjective norm has a positive but not significant effect on the intention to take halal travel in generation Z. Although both have a positive direction, research conducted by Suki and Salleh (2018) found that the influence of the subjective norm was significant on the intention to visit the retail store [7]. The same thing happened to the generation Y sample, where the influence of subjective norms is positive and significant towards Halal tourism intentions. For the attitude variable, the results of the study found a negative and not significant effect for generation Y. Contrary to these results, the effect of attitude towards intention to Halal tourism generation $\mathrm{Z}$ was positive and significant. The research of Suki and Salleh (2018) found the same results as the results of Generation Z, which were positive and significant. Nursalwani and Zulariff tested the influence of attitude toward intention to consume chocolate bar that has halal label. They found positive and significant effect on this relationship [19].

The next variable is perceived behavioral control. Both for generation $\mathrm{Y}$ and $\mathrm{Z}$ produce the same effect which is positive but not significant. This finding is contrary to research done by Khalek and Ismail (2015). They study at Generation Y in Malaysia and found that the three variables of TPB have predominantly influenced prediction of halal food consumption [20]. Next, Suki and Salleh (2018) also found that perceived behavioral control had a positive and significant effect on the intention to visit retail stores [7].

Table 3. Multiple Regression Analysis of Gen Y

Coefficients

\begin{tabular}{|c|c|c|c|c|c|c|}
\hline & \multirow[t]{2}{*}{ Model } & \multicolumn{2}{|c|}{$\begin{array}{l}\text { Unstandardized } \\
\text { Coefficients }\end{array}$} & \multirow{2}{*}{$\begin{array}{c}\text { Standardized } \\
\text { Coefficients }\end{array}$} & \multirow[t]{2}{*}{$\mathrm{t}$} & \multirow[t]{2}{*}{ Sig. } \\
\hline & & $\mathrm{B}$ & Std. Error & & & \\
\hline \multirow{6}{*}{1} & (Constant) & .818 & 2.124 & & .385 & .703 \\
\hline & Subjective & & & & & \\
\hline & Norms & .700 & .194 & .767 & 3.610 & .001 \\
\hline & Attitude & -.167 & .248 & -.135 & -.673 & .506 \\
\hline & $\begin{array}{l}\text { Perceived } \\
\text { Behavioral } \\
\text { Control }\end{array}$ & .036 & .252 & .029 & .144 & .886 \\
\hline & Religiosity & .114 & .175 & .108 & .654 & .517 \\
\hline
\end{tabular}

a. Dependent Variable: Intention

Table 4: Multiple Regression Analysis of Gen Z

Coefficients

\begin{tabular}{llllll}
\hline \multirow{2}{*}{ Model } & \multicolumn{2}{c}{$\begin{array}{l}\text { Unstandardized } \\
\text { Coefficients }\end{array}$} & $\begin{array}{c}\text { Standardized } \\
\text { Coefficients }\end{array}$ & t & Sig. \\
\cline { 2 - 4 } & B & Std. Error & Beta & & \\
\hline
\end{tabular}




\begin{tabular}{|c|c|c|c|c|c|c|}
\hline & (Constant) & 2.486 & .997 & & 2.494 & .015 \\
\hline & Subjective & & & & & \\
\hline & Norms & .177 & .096 & .242 & 1.853 & .068 \\
\hline \multirow{3}{*}{1} & Attitude & .281 & .133 & .305 & 2.112 & .039 \\
\hline & $\begin{array}{l}\text { Perceived } \\
\text { Behavioral } \\
\text { Control }\end{array}$ & .044 & .099 & .050 & .445 & .658 \\
\hline & Religiosity & 198 & .094 & .273 & 2.119 & .038 \\
\hline
\end{tabular}

a. Dependent Variable: Intention

The last variable in this study is religiosity. For Generation Y, religiosity has a positive but not significant effect, while for Generation $\mathrm{Z}$ it has a positive and significant effect. The results of this study are somewhat surprising because usually older age groups have a high level of religiosity. But in this research, generation $\mathrm{Y}$ religiosity does not affect their intention to do Halal tourism. Research by Zakaria et al (2016) found that in the context of intention to buy halal food, religiosity contributed to positive effect on purchase intention of halal certified product [21]. So does the research by Awan et al (2015), religious belief has positive and significant impact on halal purchase intention [15].

\section{Conclusions}

Research on Halal tourism is very important to do since there are currently many positive things that can be achieved from this market segment. The Indonesian government strongly supports this halal tourism as evidenced by various laws to be the basis for making decisions on halal tourism. In addition, various strategies have also been devised to develop halal tourism in Indonesia. However, it turns out that there are still many respondents who do not know about halal tourism, so the government must further increase the program's socialization in the future so that its achievements are more optimal.

The results of the study for generation $Y$ concluded only subjective norms that significantly affected Halal tourism, while for generation $\mathrm{Z}$, attitude and religiosity had a significant effect. For the older generation, it seems that doing something in accordance with the norm is important. Unlike the younger generation, they are more willing to act according to their wishes. The interesting thing is that for the younger generation, religiosity also becomes a determining factor in their intention to do halal tourism compared to the older ones.

\section{References}

[1] A. Vargas-sanchéz and M. Perano, "Halal Tourism through the Lens of Generation Z in a Muslim Majority Country: Implications on Tourist Services," Int. J. Bus. Manag., vol. 13, no. 9, pp. 36-49, 2018.

[2] E. Bogan and M. Sariisik, "Halal tourism: conceptual and practical challenges," J. Islam. Mark., vol. 10, no. 1, pp. 87-96, 2019. 
[3] S. Agmasari, "Apa itu halal travel 2.0 yang diprediksi jadi tren tahun ini?," Kompas.com, 2019.

[4] R. Qaddhat, F. Attaalla, and M. M. Hussein, "Halal Tourism: Evaluating Opportunities and Challenges in the Middle East 'Jordan and Egypt,"' J. Fac. Tour. Hotel., vol. 10, no. 2, pp. $377-$ 390, 2016.

[5] M. Shakona, K. F. Backman, S. Backman, W. Norman, Y. Luo, and L. Duffy, "Understanding the traveling behavior of Muslims in the United States," Int. J. Cult. , Tour. Hosp. Res., vol. 9, no. 1, pp. 22-35, 2015.

[6] A. G. Rashid, "Religious tourism - a review of the literature," J. Hosp. Tour. Insights, vol. 1, no. 2, pp. 150-167, 2018.

[7] N. M. Suki and A. S. A. Salleh, "Mediating effect of Halal image on Muslim consumers, intention to patronize retail stores Some insights from Malaysia,” J. Islam. Mark., vol. 9, no. 2, pp. 338-355, 2018.

[8] E. M. Elias, S. N. Othman, and A. M. Saifudin, "Halal Awareness and Knowledge among Muslim's Student Entrepreneurship Program: A Preliminary Study," in 2nd International Conference on Business Global \& Social Entrepreneurship, 2016, no. March, pp. 1-8.

[9] Y. A. Aziz and N. V. Chok, "The Role of Halal Awareness, Halal Certification, and Marketing Components in Determining Halal Purchase Intention Among Non-Muslims in Malaysia: A Structural Equation Modeling Approach,” J. Int. Food Agribus. Mark., vol. 25, no. 1, pp. 1-23, 2013.

[10] I. Ajzen, “The Theory of Planned Behavior,” Organ. Behav. Hum. Decis. Process., vol. 50, pp. $179-211,1991$.

[11] R. J. Vallerand, L. G. Pelletier, P. Deshaies, J.-P. Cuerrier, and C. Mongeau, "Ajzen and Fishbein Theory of Reasoned Action as Applied to Moral Behavior - A Confirmatory Analysis," J. Pers. Soc. Psychol., vol. 62, no. 1, pp. 98-109, 1992.

[12] N. Syahirah and A. A. Mohammed, "Islamic Hotel Service : A Conceptual Model," in Prosiding Pengurusan Halal Ekonomi dan Perniagaan, 2016, no. November, pp. 182-190.

[13] N. M. Suki and A. S. A. Salleh, "Does Halal image strengthen consumer intention to patronize Halal stores? Some insights from Malaysia," Joiurnal Islam. Mark., vol. 7, no. 1, pp. 120-132, 2016.

[14] S. W. McDaniel and J. J. Burnett, "Consumer religiosity and retail store evaluative criteria," J. Acad. Mark. Sci., vol. 18, no. 2, pp. 101-112, 1990.

[15] H. M. Awan, A. N. Siddiquei, and Z. Haider, "Factors affecting Halal purchase intention evidence from Pakistan' s Halal food sector Management Research Review Article information :," Manag. Res. Rev., vol. 38, no. 6, pp. 640-660, 2015.

[16] F. Haq and H. Y. Wong, "Is Spiritual tourism a new strategy for marketing Islam?," J. Islam. Mark., vol. 1, no. 2, pp. 136-148, 2010.

[17] S. Krishnan, C. M. C. Omar, I. Zahran, N. Syazwan, and S. Alyaa, "The Awareness of Gen Z's toward Halal Food Industry," Management, vol. 7, no. 1, pp. 44-47, 2017.

[18] A. Anismar, D. Satria, and M. Ali, "Religious Tourism : Concept of Community-Based Tourism in Aceh Singkil , Indonesia Tourism," in Proceedings of MICoMS, 2018, pp. 283-288.

[19] M. Nursalwani and A. Latiff, "The Effect of Attitude , Subjective Norm and Perceived Behaviour Control Towards Intention of Muslim Youth at Public Universities in Kelantan to Consume Halal Labelled Chocolate Bar Product," Can. Soc. Sci., vol. 13, no. 2, pp. 43-48, 2017.

[20] A. A. Khalek and S. H. S. Ismail, "Why Are We Eating Halal - Using the Theory of Planned Behavior in Predicting Halal Food Consumption among Generation Y in Malaysia," Int. J. Soc. Sci. Humanit., vol. 5, no. 7, pp. 608-612, 2015.

[21] Z. Zakaria, M. N. A. Majid, Z. Ahmad, and N. Z. Zakaria, "Influence of HALAL Certification on Customers 'Purchase Intention : Rhetoric or Reality," in Terengganu International Business and Economic Conference, 2016, pp. 589-600. 